\title{
Pengembangan Game Edukasi "Kata Fisika" Berbasis Android untuk Anak Sekolah Dasar pada Materi Konsep Gaya
}

\author{
Muhammad Erfan ${ }^{1]}$, Arif Widodo ${ }^{2]}$, Umar $^{3]}, \operatorname{Radiusman}^{4]}$, Tursina Ratu $^{5]}$ \\ Universitas Mataram \\ Universitas Samawa \\ E-mail: muhammaderfan@unram.ac.id \\ arifwidodo@unram.ac.id \\ umarelmubaraq90@unram.ac.id \\ radius_saragih88@unram.ac.id \\ tursinaratu@universitas-samawa.ac.id
}

\begin{abstract}
Abstrak
Lebih tertariknya anak-anak kepada smartphone daripada materi belajar yang dijelaskan oleh pendidik tentunya menuntut para pendidik untuk mencari cara lain dalam menarik minat peserta didik untuk belajar. Salah satu upaya yang dapat dilakukan pendidik dalam mengatasi masalah ini adalah mengembangkan media pembelajaran berbasis game. Oleh karena itu, penelitian ini bertujuan untuk (1) Mengembangkan game edukasi "Kata Fisika" berbasis Android sebagai media pembelajaran anak sekolah dasar pada konsep gaya, (2) Mengetahui penilaian kelayakan oleh ahli media dan ahli materi terhadap game edukasi "Kata Fisika" berbasis Android yang dikembangkan untuk anak sekolah dasar, dan (3) mengetahui peniaian dan respon peserta didik terhadap game edukasi "Kata Fisika" berbasis Android sebagai media pembelajaran untuk anak sekolah dasar pada materi konsep gaya. Penelitian ini merupakan penelitian pengembangan dan model yang digunakan yaitu model pengembangan 4-D yang terdiri atas 4 tahap utama yaitu: (1) Define (mendefinisikan); (2) Design (merancang); (3) Develop (mengembangkan); dan (4) Disseminate (penyebaran). Analisis data dilakukan secara kualitatif. Hasil pengembangan diperoleh game edukasi yang telah divalidasi oleh ahli media dan dinyatakan layak dengan skor rata-rata 3,88, ahli materi dengan kategori layak dengan skor rata-rata 3,39, dan berdasarkan hasil penilaian oleh pengguna (peserta didik) diperoleh bahwa game edukasi ini dinyatakan sangat baik untuk dikembangkan lebih lanjut dengan skor rata-rata 4,15. Berdasarkan hasil tersebut, diperoleh bahwa game edukasi "Kata Fisika" berbasis Android dikategorikan layak dan bisa digunakan pada pembelajaran IPA materi Konsep Gaya pada peserta didik Sekolah Dasar.
\end{abstract}

Kata Kunci: game, android, IPA

\section{Development of Android-Based Educational Game "Kata Fisika" for Elementary School Children on Concept of Force}

\begin{abstract}
Children are more interested in smartphones than the learning materials explained by the teacher certainly requires educators to find other ways to attract students to learn. One effort that can be done by educators is developing game-based learning media.
\end{abstract}


Therefore, this study aims to (1) Develop an Android-based educational game "Kata Fisika" as a learning media for elementary school children on force concept, (2) study the assessment of media experts and material experts on the learning media of the Android-based educational game "Kata Fisika" developed for elementary school children, and (3) know the assessment and response of students to the Android-based educational game "Kata Fisika" as a learning media for elementary school children on force concept. This research is development research with Research and Development $(R \& D)$ design and the model used is a 4-D development model consisting of four main stages, namely: (1) Define; (2) Design; (3) Develop; and (4) Disseminate. Data analysis was carried out qualitatively. Development results obtained by educational games that have been tested to media experts and declared worthy with an average score of 3.88, material experts with a decent category with an average score of 3.39, and based on the results of assessments by users (students) obtained that the game was declared very good to be developed further with the score of 4.15. Based on these results, the educational game "Kata Fisika" is categorized as feasible and could be used in learning the science concept of force in elementary school students.

Keywords: game, android, science

\section{PENDAHULUAN}

Media pembelajaran termasuk salah satu dari lima aspek penting yang wajib ada dalam proses pembelajaran selain tujuan, materi, metode, media, dan evaluasi pembelajaran. Kelima aspek penting ini saling berkaitan satu sama lain sehingga pemilihan metode mengajar tertentu akan berdampak pada pemilihan media pembelajaran yang sesuai dengan tanpa melupakan ketiga aspek penting lainnya yaitu tujuan, materi, dan evaluasi pembelajaran (Falahudin, 2014).

Istilah "media" asalnya dari bahasa Latin yaitu "medium" yang berarti "perantara" atau "pengantar". Media merupakan alat atau sarana yang digunakan untuk menyampaikan pesan atau informasi belajar yang ingin disalurkan oleh sumber asal pesan kepada target, sasaran atau penerima pesan tersebut. Penggunaan media pengajaran dapat bermanfaat dan membantu mencapai kesuksesan dalam belajar (Mahnun, 2012). Menurut Association for Education and Communication Technology (AECT) sebagaimana dikutip oleh Muhson, media adalah segala bentuk dan cara yang dipergunakan untuk berjalannya proses informasi. Lebih lanjut, Muhson menyatakan bahwa media pembelajaran merupakan "perangkat lunak" (Software) yang berupa pesan atau informasi pendidikan yang disajikan dengan memakai suatu peralatan bantu (Hardware) agar pesan/informasi tersebut dapat sampai kepada mahasiswa (Muhson, 2010). Secara terperinci, Gerlach menyatakan bahwa media umumnya meliputi orang, bahan, peralatan, atau kegiatan yang menciptakan kondisi yang memungkinkan siswa memperoleh pengetahuan, keterampilan, dan sikap. Jadi dari penjelasan ini media tidak hanya alat perantara seperti televisi, radio, slide, bahan cetakan, tetapi juga meliputi orang atau manusianya sebagai sumber belajar atau kegiatan seperti diskusi, seminar, karyawisata, simulasi, dan lain sebagainya yang dikondisikan dan bertujuan untuk menambah ilmu dan wawasan, mengubah sikap peserta didik, dan atau untuk menambah 
pengetahuan serta keterampilan (Mahnun, 2012). Dari beberapa pendapat tersebut secara umum dapat diketahui bahwa media pembelajaran merupakan alat atau perantara yang dapat menghubungkan atau menyampaikan pesan-pesan atau informasi materi pembelajaran dari pendidik ke peserta didik dalam proses belajar mengajar.

Relevansi dalam pemilihan tipe media pembelajaran merupakan suatu hal yang juga penting diperhatikan oleh pendidik sebagaimana pentingnya pendidik memilih metode yang tepat dalam proses pembelajaran. Pemanfaatan media yang relevan di dalam kelas tentunya dapat mengoptimalkan proses pembelajaran dimana bagi pendidik, media pembelajaran dapat digunakan untuk membantu mengkonkritkan konsep atau gagasan dan membantu memberikan motivasi kepada peserta didik untuk belajar aktif. Selain itu secara khusus bagi peserta didik, media selain dapat untuk menjadi jembatan untuk berpikir kritis, media pembelajaran juga dapat berperan sebagai arahan untuk berbuat (Karo-Karo \& Rohani, 2018). Oleh karena itu pendidik harus bersifat tanggap dalam memilih media pembelajaran sebagaimana pendidik memilih metode pembelajaran apa yang akan digunakan dalam proses belajar mengajar sehingga kebermanfaatan media pembelajaran maupun materi pembelajaran dapat tercapai secara maksimal.

Berkaitan dengan relevansi dan kebermanfaatan media dalam proses pembelajaran, pendidik atau guru kiranya perlu mengetahui kebutuhan dalam proses belajar mengajar dan permasalahan-permasalahan yang dihadapi oleh peserta didik tentang materi yang sedang dan akan diajarkan. Raharjo dalam Mahnun menyatakan bahwa dalam memilih media pembelajaran sebaiknya memperhatikan prinsip-prinsir tertentu. Yaitu; (a) Kejelasan maksud dan tujuan dalam memilih media; apakah media tersebut bertujuan untuk keperluan hiburan, memberikan informasi umum, pembelajaran tertentu dan sebagainya, (b) Familiaritas media, yaitu tentang sifat dan ciri-ciri media yang akan dipilih, dan (3) Sejumlah media dapat diperbandingkan karena terdapat beberapa pilihan yang sekiranya lebih sesuai dengan tujuan pengajaran yang akan dilangsungkan. Selanjutnya Winkel dalam Mahnun juga mengatakan bahwa dalam memilih media selain melihat kesesuiannya dengan tujuan intruksional khusus, materi pelajaran, prosedur didaktis dan bentuk pengelompokan siswa, juga harus mempertimbangkan masalah faktor biaya, waktu dan peralatan apakah tersedia atau tidak, apakah ketersediaan aliran listrik stabil atau tidak, bagaimana kualitas teknis dari media tersebut, keadaan ruang kelas, dan apakah pendidik mampu dan menguasai pemanfaatan media secara tepat. Oleh karena itu, pendidik selain dituntut untuk mampu menyajikan materi pembelajaran, juga harus mampu memilih metode maupun media pembelajaran yang tidak hanya sesuai untuk digunakan tetapi juga dengan mempertimbangkan berbagai macam aspek sehingga diperoleh media pembelajaran yang efektif dalam proses pembelajaran serta baik untuk digunakan.

Media pembelajaran yang baik tidak hanya mampu meningkatkan motivasi dan keinginan peserta didik untuk belajar secara mandiri, tetapi juga dapat berperan untuk mengatasi kebosanan dalam belajar di kelas. Oleh karena itu, pendidik dituntut untuk tidak hanya mampu memotivasi, tetapi juga 
mampu mengembangkan dan memanfaatkan media pembelajaran yang dapat digunakan baik di dalam kelas maupun di luar kelas (Tafonao, 2018). Selain itu, media pembelajaran yang harus dan wajib dikembangkan oleh pendidik selain mampu melatih level berpikir kognitif dan mengasah karakter peserta didik, harapannya juga harus mempertimbangkan dan melibatkan teknologi informasi dan komunikasi yang semakin pesat dan tentunya akan menjadi tantangan tersendiri bagi para peserta didik pada masanya kelak.

Semakin pesatnya teknologi informasi dan komunikasi yang sudah terintegrasi dalam dunia pendidikan, tentunya memberikan banyak pilihan bagi pendidik untuk memilih ataupun mengembangkan sendiri media pembelajaran yang digunakan dalam proses pembelajaran. Proses pembelajaran yang mengimplementasikan teknologi informasi tentunya memberikan banyak variasi dalam media pembelajaran sehingga akan berdampak positif bagi hasil belajar peserta didik (Ramdhani \& Wulan, 2012). Selain itu, belajar dengan melibatkan penggunaan multimedia memberikan dampak positif tidak hanya terhadap hasil belajar tetapi juga pada minat dan motivasi peserta didik (Ramdhani \& Muhammadiyah, 2015). Oleh karena itu penting bagi pendidik untuk belajar tentang variasi dan pengembangan pada media pembelajaran yang digunakan pada proses pembelajaran sehingga pada akhirnya pendidik mampu mengembangkan media pembelajaran ataupun multimedia yang terintegrasi teknologi informasi dan komunikasi untuk menarik minat dan motivasi peserta didik untuk lebih tertarik dalam belajar.
Integrasi teknologi informasi yang sudah kian merambah dalam pola kehidupan manusia saat ini tidak hanya dalam hal penyebaran informasi yang kian cepat tetapi juga kebutuhan akan berbagai gadget yang sudah kian menjadi kebutuhan primer. Pada Saat ini seseorang sudah tidak dapat berpisah dengan gadget seperti tablet, smartphone, dan PDA dan tidak hanya menggunakannya sebagai alat komunikasi dan bersosial media tetapi juga sebagai sarana bermain game. Millward Brown menyatakan bahwa seseorang bisa menghabiskan 7 (tujuh) jam sehari dalam mengakses gadget dimana di sebagian besar negara, gadget yang digunakan adalah smartphone (Millward Brown, 2014). Pendapat ini didukung oleh Childwise yang menyatakan bahwa di tahun 2017 dalam perminggu terdapat $54 \%$ anak menggunakan smartphone mereka untuk mendengarkan musik, $51 \%$ untuk menonton video, $41 \%$ untuk bermain game, serta $60 \%$ menggunakan smartphone untuk berselancar di internet atau untuk online. Smartphone sekarang ini merupakan gadget wajib untuk mendengarkan musik, akses online, bermain game (gaming), konten video dan untuk membaca, serta sebagai bahan entertainment bagi anak muda yang dapat diakses kapanpun dan dimanapun (CHILDWISE, 2017). Data terbaru mengenai penggunaan akses paket data pada gadget yang diperoleh dari Nusaresearch yang mensurvey 2.824 orang responden diketahui bahwa sebagian besar laki-laki menggunakan atau menghabiskan paket data lebih banyak daripada wanita. Selain itu, sebagian besar paket data dihabiskan dengan mengakses video di youtube, bermain game, serta bermedia sosial. Melihat besarnya pengguna gadget yang mana pengguna menggunakannya sebagai media bermain game dan 
sebagian besar pengguna tersebut adalah anak-anak, pendidik diharapkan jangan hanya melarang peserta didik dalam menggunakan smartphone dalam bermain game digital tetapi juga didorong untuk dapat berinteraksi dengan anak-anak dan sekaligus mengarahkan mereka agar dapat memilih atau memainkan permainan yang tujuannya untuk mendidik. Selain itu pendidik juga dapat mengintegrasikan game tersebut dalam proses pembelajaran.

Pembelajaran berbasis game atau Game-Based Learning bukan merupakan hal baru dalam pendidikan dan pembelajaran. Game-Based Learning (GBL) dirancang untuk mengkombinasikan kegiatan pembelajaran dan permainan untuk meningkatkan hasil belajar, termasuk kemampuan mengingat informasi dan aplikasinya pada dunia nyata (Liu, 2016). Lebih lanjut, Game-Based Learning merupakan metode pembelajaran yang tidak hanya menggabungkan berbagai konten pendidikan atau prinsip-prinsip pembelajaran ke dalam video game tetapi juga bertujuan untuk melibatkan pengguna atau peserta didik secara aktif dalam proses pembelajaran (Erfan \& Ratu, 2017). Oleh karena itu, penggunaan Game-Based Learning diharapkan tidak hanya dapat membuat peserta didik tertarik dan larut dalam permainan yang merupakan bagian dalam proses pembelajaran tetapi juga ingatan peserta didik dapat bertahan lebih lama karena di dalam proses pembelajaran yang melibatkan permainan, tidak hanya melibatkan keterampilan kognitif tetapi juga keterampilan afektif, emosional, serta sosial anak (Rais, Aryani, Ahmar, Arfandi, \& Ahmad, 2018).

Aktifitas paling cocok bagi anak-anak dalam membangun penge- tahuannya adalah melalui kegiatan bermain. Kegiatan bermain yang dimaksudkan dalam hal ini adalah kegiatan atau aktivitas mendasar anak yang dilakukan sendiri, bersama pengajar, keluarga, teman sebaya maupun orangtua yang mana kegiatan tersebut dilakukan tanpa paksaan dan secara sukarela, menyenangkan diri anak tersebut, dengan bermain anakanak akan mampu memahami berbagai aturan-aturan, mampu bersosialisasi dan bekerjasama dengan baik. Hakikat bermain menurut Tedjasaputra adalah belajar bagi anak, sebab dengan bermain, anak dapat menambah kemampuannya dan mampu mengembangkan dirinya (Azizah, 2016).

Kegiatan bermain sebetulnya dapat memberikan banyak manfaat bagi peserta didik. Kegiatan bermain tidak hanya dapat meningkatkan keterampilan sosial, afektif, dan penguasaan bahasa anak tetapi kegiatan bermain juga dapat mengembangkan keterampilan kognitif anak serta melalui kegiatan bermain pendidik lebih mudah dalam menyampaikan konsep-konsep yang ada dalam materi pembelajaran. Melalui kegiatan bermain, anak-anak tidak hanya dapat mengembangkan aspek motoriknya, tetapi juga aspek fisik, kognitif, bahasa, emosi, sosial, serta daya imajinasi anak (Rais et al., 2018). Banyaknya manfaat dari kegiatan bermain ini juga didukung fakta yang dikemukakan oleh Montessori dimana bermain dapat menstimulasi otak anak (Suyadi, 2014).

Seiring dengan berkembangnya teknologi informasi dan komunikasi yang tentunya semakin cepat pada abad ini, kegiatan bermain tidak hanya dapat dilakukan dengan permianan yang sifatnya nyata tetapi juga bersifat virtual yang tergabung dalam suatu server global dan fugur-figur pemainnya 
diwakili oleh animasi maupun gambargambar bergerak yang dimainkan oleh pemain. Bermain melalui permainan animasi yang dapat dilakukan dengan menggunakan media elektronik seperti handphone yang mampu mengopersikan permainan digital (Rais et al., 2018).

Perkembangan teknologi yang membuat anak-anak semakin kecanduan terhadap smartphone membuat orang tua maupun pendidik bertanggungjawab dalam mengevaluasi serta mengarahkan peserta didik, serta mampu memilihkan permainan (game) yang tidak hanya mampu menghibur tetapi juga dapat memberikan edukasi pada anak (Fujiati, Nasari, Rahayu, \& Sanjaya, 2018).

Berdasarkan kategori permainan yang ada di Play Store terdapat 17 (tujuh belas) macam kategori pemainan yang dapat dipilih dan di unduh oleh pengguna smartphone Android. Kategori-kategori tersebut diantaranya adalah permaian arkade, balapan, kartu, kasino, kata, laga, musik, olahraga, papan (board games), pendidikan (education games), petualangan, Real Player Games (RPG), permainan santai, simulasi, strategi, teka-teki, serta trivia (tebak-tebakan). Dari kesemua kategori tersebut, game dengan kategori arkade yaitu Subway Surfers yang dikembangkan oleh Kiloo merupakan game dengan rekor unduhan (download) terbanyak (Panier, 2019). Walaupun sudah diberikan kategori tersendiri untuk game edukasi, tetapi kuantitas atau jumlah game dalam kategori edukasi masih tergolong sedikit jika dibandingkan dengan kategori-kategori yang lain. Hal ini tentu saja menjadi suatu kesempatan bagi pendidik untuk mengembangkan berbagai game edukasi.

Game edukasi menurut beberapa peneliti dalam bidang pendidikan mempunyai banyak kegunaan dimana salah satunya adalah game edukasi dapat berkontribusi dalam memfokuskan keterampilan seseorang serta lebih menarik perhatian daripada metode pengajaran lainnya (Turan, Köklükaya, \& Yıldırım, 2020). Beberapa riset sebelumnya menunjukkan bahwa game komputer atau video game sebenarnya memiliki pengaruh positif dan efektif dalam meningkatkan proses pembelajaran (Baek, Park, \& Han, 2016). Selain itu dengan adanya kegiatan bermain game juga dapat me-ningkatkan perkembangan fungsi otak (Connolly, Boyle, MacArthur, Hainey, \& Boyle, 2012). Integrasi game edukasi dalam pembelajaran matematika memberikan peningkatan yang signifikan bagi peserta didik sekolah dasar dalam mengenal bilangan (Nagle, Wolf, Riener, \& Novak, 2014).

Pembelajaran Sains atau Ilmu Pengetahuan Alam (IPA) di tingkat Sekolah Dasar (SD) adalah pondasi awal penanaman ide kepada peserta didik untuk menjadi saintis yang sejati, hal ini tentunya menjadi tuntutan bagi pendidik untuk tidak hanya memahami seutuhnya karakteristik anak SD tersebut tetapi juga mampu menyampaikan konsep-konsep IPA yang sesuai (Tursinawati, 2013). Oleh karena itu, tujuan diberikannya materi Sains atau IPA untuk peserta didik tingkat sekolah dasar yakni peserta didik dapat memahami konsep dasar Sasins atau IPA yang kemudian dapat dihubungkan secara kontekstual dalam kehidupan peserta didik tersebut seharihari. Selain itu, peserta didik juga dapat meumbuhkan rasa syukur terhadap Tuhan Yang Maha Esa atas semua kebesaran-Nya. Berdasarkan uraian tersebut, dapat diketahui pentingnya mengajarkan IPA bagi peserta didik khususnya peserta didik tingkat sekolah dasar. 
Salah satu konsep dalam pembelajaran IPA yang harus dikuasai oleh peserta didik tingkat sekolah dasar adalah konsep gaya. Bruner, Goodnow, dan Austin menyatakan bahwa sebuah konsep (khususnya konsep sains) memiliki lima elemen penting yaitu: (1) Nama, (2) Definisi, (3) Lambang/Simbol/Atribut, (4) Nilai, serta (5) Contoh (Chiappetta \& Koballa, 2014)(Erfan \& Ratu, 2018). Kelima macam elemen penting dalam suatu konsep ini tentunya harus dikuasai peserta didik untuk menghindari salah konsep atau miskonsepsi pada peserta didik.

Miskonsepsi atau pemahaman konsep yang tidak atau kurang tepat tehadap konsep IPA banyak terjadi pada peserta didik di berbagai negara mulai dari tingkat Sekolah Dasar (SD) hingga mahasiswa di perguruan tinggi (Akbas \& Gencturk, 2011)(Timur, 2012). Miskonsepsi yang ditemukan hampir disemua materi IPA dari gaya dan gerak, bumi dan antariksa, tumbuhan dan makhluk hidup (Laksana, 2017). hal ini tentunya menjadi catatan tersendiri bagi para pendidik khususnya pada materi konsep gaya mengenai bagaimana caranya agar setelah mempelajari konsep gaya, peserta didik tidak ada yang mengalami miskonsepsi.

Konsep gaya dalam pembelajaran IPA sekolah dasar diberikan pada kelas 4 (kelas tinggi) dan lebih menitik beratkan pemahaman mengenai istilah-istilah dalam konsep gaya seperti inersia, gaya gravitasi, tarikan, dorongan, berbagai jenis gaya dan berbagai akibat yang ditimbulkan oleh gaya. Istilah inersia, gaya, definisi gaya, tarikan, dorongan, interaksi antara dua buah medan gaya sangat penting untuk dijelaskan pada peserta didik sekolah dasar mengingat beberapa istilah tersebut ada yang sedikit sama dengan istilah lain yang mungkin sering dijumpai pesesrta didik tetapi memiliki makna yang berbeda seperti istilah gaya pada IPA tentu saja berbeda dengan istilah gaya pada seseorang ketika sedang difoto. Istilah inersia yang mungkin sedikit asing bagi peserta didik tingkat sekolah dasar dapat dijelaskan dengan memberikan contoh pada saat peserta didik yang menaiki kendaraan yang tiba-tiba terdorong ke depan ketika sopir kendaraan menginjak pedal rem. Selain itu, miskonsepsi sering terjadi pada peserta didik tingkat sekolah dasar yang menganggap bahwa benda jatuh karena adanya gaya gravitasi. Benda jatuh tentu saja karena tidak ada gaya lain yang lebih besar dan arahnya berlawanan dengan gaya graviasi sehingga gaya lain tersebut dapat menahan gaya gravitasi. Miskonsepsi seperti inilah yang tentunya harus diatasi oleh pendidik ataupun calon pendidik sehingga apabila konsep yang tertanam dalam benak peserta didik adalah konsep yang benar, maka konsep tersebut akan terus terbawa hingga peserta didik tersebut beranjak dewasa.

Selain dijelaskan dengan uraian dan contoh-contoh penerapan gaya, peserta didik pada tingkat sekolah dasar juga diproyeksikan mengingat berbagai istilah-istilah yang berkaitan dengan konsep gaya. Salah satu upaya agar peserta didik dapat mengingat istilahistilah dalam konsep gaya tersebut yaitu dengan memasukkan istilah-istilah tersebut dan menjadikannya konten dalam suatu permainan (game). Oleh karena itu, pengembangan game edukasi ini bertujuan agar peserta didik dapat mempelajari konsep gaya secara menyenangkan melalui pembelajaran yang melibatkan game (permainan) berbasis Android.

\section{METODE}

Penelitian ini termasuk penelitian pengembangan dengan desain 
penelitian Research and Development $(R \& D)$ dan menggunakan model 4-D yang terdiri atas 4 tahap utama yaitu: (1) Define (mendefinisikan); (2) Design (merancang); (3) Develop (mengembangkan); dan (4) Disseminate (menyebarkan). Namun, dalam penelitian ini hanya dibatasi pada tahap ketiga yaitu tahap pengembangan dan tidak sampai pada tahap diseminasi karena keterbatasan biaya dan sebagainya.

Instrumen yang digunakan untuk mengumpulkan data dalam penelitian ini adalah lembar angket ahli media dan ahli materi. Angket ahli materi dan ahli media digunakan untuk mengetahui apakah media layak atau tidak menurut ahli media maupun oleh ahli materi. Setelah media dinyatakan layak oleh para ahli, selanjutnya media diujicobakan di lapangan. Uji coba ini dilakukan pada mahasiswa semester 5 (lima) Program Studi Pendidikan Guru Sekolah Dasar Universitas Mataram yang dimana hampir sebagian besar mahasiswa Program Studi Pendidikan Guru Sekolah Dasar Universitas Mataram sudah memiliki smartphone dengan Operating System berbasis Android yang kompatibel untuk menjalankan game ini.

Data hasil penelitian dianalisis secara deskriptif kuantitatif. Penilaian uji kelayakan untuk angket mahasiswa, angket validasi ahli media dan angket validasi ahli materi dilakukan dengan menggunakan skala Likert.

Total skor yang didapat dari penilai selanjutnya dihitung total nilai tiap aspek dari keseluruhan responden. Responden pada penelitian ini adalah dua orang ahli media, dua orang ahli materi serta beberapa orang pengguna. Setelah nilai total diperoleh selanjutnya dibuat rentang kelayakan media secara kualitatif. Kriteria penilaian kelayakan oleh ahli media, ahli materi dan pengguna ditunjukkan pada Tabel 1 .

Tabel 1. Kriteria Penilaian Kelayakan Media

\begin{tabular}{cc}
\hline Rentang Skor & Kategori \\
\hline $\mathrm{X} \geq \mathrm{Xi}+1,80 \mathrm{SBi}$ & Sangat Layak \\
$\mathrm{Xi}+0,60 \mathrm{SBi}<\mathrm{X}<\mathrm{Xi}+1,8 \mathrm{SBi}$ & Layak \\
$\mathrm{Xi}-0,60 \mathrm{SBi}<\mathrm{X}<\mathrm{Xi}+0,60 \mathrm{SBi}$ & Cukup \\
$\mathrm{Xi}-1,80 \mathrm{SBi}<\mathrm{X}<\mathrm{Xi}+0,60 \mathrm{SBi}$ & Kurang Layak \\
$\mathrm{X} \leq \mathrm{Xi}-1,80 \mathrm{SBi}$ & Tidak Layak \\
\hline
\end{tabular}

Kriteria konversi data kuantitatif ke kualitatif dapat disederhanakan dan ditunjukkan pada Tabel 2.

\begin{tabular}{ccc} 
Tabel 2. Pedoman & Konversi & Data \\
Kuantitatif & Menjadi & Data \\
Kualitatif & \\
\hline Rentang Skor & Skor & Kategori \\
\hline $\mathrm{X} \geq 4,08$ & 5 & Sangat Layak \\
$3,36<\mathrm{X}<4,08$ & 4 & Layak \\
$2,64<\mathrm{X}<3,36$ & 3 & Cukup \\
$1,92<\mathrm{X}<2,64$ & 2 & Kurang Layak \\
$\mathrm{X} \leq 1,92$ & 1 & Tidak Layak \\
\hline
\end{tabular}

\section{HASIL DAN PEMBAHASAN Preview Media Hasil Pengembangan}

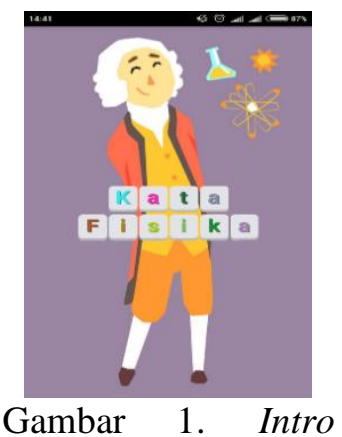

Game Kata Fisika

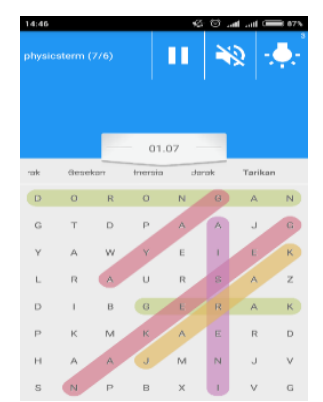

Gambar 3. Contoh Jawaban

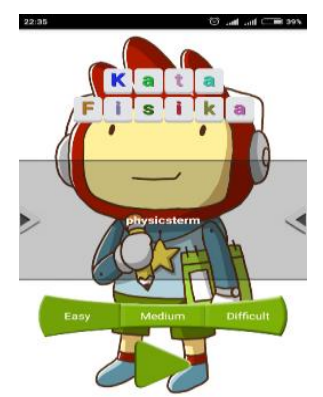

Gambar 2. Level Bermain

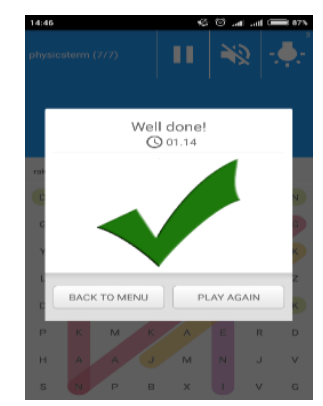

Gambar 4. Pemain Berhasil 
Gambar 1 mengenai pengenalan atau intro pada halaman pembuka game. Intro pada game ini berfungsi sebagai indikator bagi pemain bahwa aplikasi permainan yang terpasang pada smartphone berbasis android dapat berjalan dengan baik dan selain itu juga dapat menginformasikan pada pengguna bahwa pada game ini akan berkaitan dengan istilah-istilah pada IPA Fisika. Karena gambar pembuka pada intro merupakan animasi kartun gambar Isaac Newton yang merupakan ilmuan atau fisikawan hebat pada masanya dalam menjelaskan konsep gaya, maka hal ini melambangkan bahwa sebagian besar materi yang ada pada game ini juga berkaitan dengan konsep gaya.

Pada Gambar 2 yang merupakan menu selanjutnya setelah Intro, pemain dapat memilih tiga level kesulitan mulai dari yang mudah (easy), sedang (medium), dan level sulit (difficult). istilah-istilah konsep pada IPA Fisika yang ada pada setiap level jumlahnya sama yaitu 10 (sepuluh) istilah dimana yang membedakan tiap level permainan adalah banyaknya huruf pengecoh dalam pencarian kata atau istilah. Secara keseluruhan, Pada level mudah terdapat 64 huruf, pada level sedang dengan 100 huruf, dan pada level sulit terdapat 144 huruf.

Pada Gambar 3 dapat dilihat contoh cara memainkan game Kata Fisika ini. Pemain dapat mencari istilah (term) konsep gaya dalam susunan huruf yang acak dengan cara mencarinya secara mendatar, menurun, diagonal naik, maupun diagonal turun.

Ketika seluruh kata istilah sudah didapatkan, maka pemain berhasil menyelesaikan permainan sebagaimana ditunjukkan pada Gambar 4. Selanjutnya pemain dapat melihat berapa lama waktu yang dibutuhkan dalam mencari istilah-istilah tersebut dan dapat memutuskan apakah ingin bermain kembali atau kembali ke menu utama (Gambar 2).

\section{Hasil Uji Validasi Media}

Uji validasi media oleh ahli digunakan untuk mengetahui layak tidaknya kualitas media pembelajaran sebelum diuji cobakan kepada pengguna. Pada tahap uji validasi ini, media diuji oleh 2 (dua) orang ahli media di Jurusan Ilmu Pendidikan Fakultas Keguruan dan Ilmu Pendidikan Universitas Mataram.

Rata-rata hasil penilaian pada empat aspek media pembelajaran disajikan pada Tabel 3.

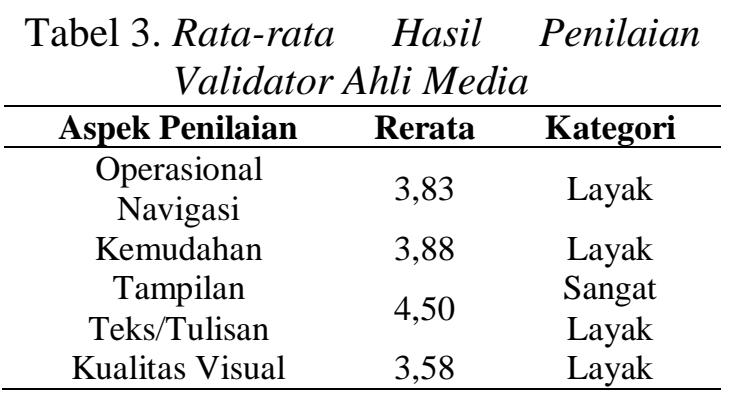

Hasil Uji Validasi Materi

Uji Validasi oleh ahli materi digunakan untuk mengetahui tingkat kualitas media pembelajaran dilihat dari aspek kelayakan materi pada tingkat Sekolah Dasar sebelum diuji cobakan kepada pengguna. Pada tahap uji validasi materi, media pembelajaran yang dikembangkan diuji oleh 2 (dua) ahli materi pembelajaran dan kurikulum di Jurusan Ilmu Pendidikan FKIP Universitas Mataram dan Guru Kelas 5 (lima) SD Negeri Repok Puyung Kecamatan Aik Dareq Kabupaten Lombok Tengah.

Rata-rata hasil penilaian pada empat aspek materi pembelajaran yang disajikan pada Tabel 4.

\begin{tabular}{ccc} 
Tabel 4. Rata-rata & Hasil & Penilaian \\
\multicolumn{3}{c}{ Validator Ahli Materi } \\
\hline Aspek Penilaian & Rerata & Kategori \\
\hline Pembelajaran & 3,25 & Cukup \\
Substansi Materi & 3,33 & Cukup \\
\hline
\end{tabular}




\begin{tabular}{ccc}
\hline Bahasa & 4,17 & Sangat Layak \\
$\begin{array}{c}\text { Kemudahan } \\
\text { Pemakaian }\end{array}$ & 3,00 & Cukup \\
\hline
\end{tabular}

\section{Hasil Uji Coba Pengguna}

Uji coba pengguna dilakukan kepada lima orang mahasiswa semester 5 (lima) program studi PGSD FKIP Universitas Mataram. Pemilihan lima orang mahasiswa ini dikarenakan pada semester 5 (lima), mahasiswa mendapatkan pembelajaran IPA SD tentang konsep gaya dan pernah melakukan peer teaching berkaitan tentang materi konsep gaya.

Rata-rata skor hasil uji coba pengguna disajikan pada Tabel 5.

Tabel 5. Rata-rata Hasil Uji Coba Pengguna (User)

\begin{tabular}{ccc}
\hline Pengguna & Rerata & Kategori \\
\hline Pengguna 1 & 4,18 & Sangat Layak \\
Pengguna 2 & 4,14 & Sangat Layak \\
Pengguna 3 & 4,09 & Sangat Layak \\
Pengguna 4 & 4,18 & Sangat Layak \\
Pengguna 5 & 4,14 & Sangat Layak \\
\hline
\end{tabular}

Dari kelima pengguna jika hasil penilaian ujicoba dirata-rata maka akan diperoleh rerata total 4,15 . Nilai ratarata total ini merupakan penilaian pengguna terhadap kelayakan media game edukasi secara umum. Berdasarkan kriteria kelayakan media yang sebelumnya telah disajikan pada Tabel 2 maka diperoleh bahwa dengan rerata total sebesar 4,15 media pembelajaran game edukasi "Kata Fisika" menurut pengguna termasuk dalam kategori sangat layak.

\section{Pembahasan}

Penelitian ini merupakan penelitian pengembangan dengan desain Research and Development (R\&D) dengan menggunakan model 4-D (define, design, develop, disseminate). Namun dalam penelitian ini hanya sampai pada tahap develop, sementara tahap disseminate belum dilakukan.
Tahap define merupakan tahap yang membahas tentang pengolahan materi pembelajaran yang sesuai dengan media yang meliputi analisis awal, analisis peserta didik, analisis konsep, analisis tugas serta perumusan target dan tujuan pembelajaran. Materi pembelajaran diperoleh pada panduan silabus dan buku guru tema 7 Indahnya Keragaman di Negeriku. Secara umum buku guru tema 7 Indahnya Keragaman di Negeriku memiliki 3 (tiga) subtema yaitu Keragaman Suku Bangsa dan Agama di Negeriku, Indahnya Keragaman Budaya Negeriku, dan Indahnya Persatuan dan Kesatuan Negeriku. Dari ketiga subtema tersebut materi konsep gaya disajikan secara tematik dalam ketiga sub tema tersebut.

Dari kumpulan materi yang ada pada buku guru diambil istilah-istilah yang berkaitan dengan konsep gaya seperti tarikan, dorongan, gaya, gerak, gesekan, gravitasi, inersia, jarak, kecepatan, dan percepatan. Dalam Game Edukasi, kata-kata istilah yang ada dalam konsep gaya dibuat acak dan peserta didik menemukan kata istilah tersebut dalam game edukasi. Semakin cepat kata istilah tersebut ditemukan, semakin tinggi skor yang didapatkan dalam game edukasi "Kata Fisika".

Tahap design, tahap ini membahas tentang pemilihan media yang meliputi jenis-jenis media audio visual yang dilibatkan seperti format gambar jpg dan png, file audio dengan ekstensi mp3. Tahap design dalam pemilihan format dibahas tentang format penilaian yang digunakan untuk validasi oleh ahli media, ahli materi dan pengguna. Fase rancangan awal lebih banyak membahas tentang tampilan antar muka yang nantinya akan disajikan pada media pembelajaran game edukasi "Kata Fisika". Proses rancangan awal ini juga dilakukan mengenai petunjuk apa saja yang harus 
diperhatikan oleh pengguna. Semua gambar pendukung baik pada intro dan menu utama dan icon aplikasi semuanya dibuat pada tahapan ini.

Tahap develop yang merupakan tahap untuk merealisasikan rancangan dari desain media pembelajaran dalam bentuk game yang sebelumnya telah direncanakan. Pembuatan media pembelajaran game edukasi "Kata Fisika" berbasis android, menggunakan template pembuatan aplikasi permainan yang disediakan oleh AppsGeyser. AppsGeyser merupakan salah satu pembuat aplikasi cuma-cuma atau gratis yang dapat mengubah konten daring menjadi suatu aplikasi Android (Besttoolbars, 2020). Melalui AppsGeyser pengguna dapat merancang dan membuat berbagai aplikasi Android hanya dengan halaman website yang dirancang dengan bahasa HTML. Selain itu, AppsGeyser juga menyediakan template game Android sederhana seperti game pencarian kata, mencocokkan gambar, serta tebak istilah tanpa melibatkan coding dan pemprograman aplikasi yang rumit.

Tahap disseminate yang dilakukan hanyalah mempublikasikan (publish) game edukasi "Kata Fisika" ke Play Store. Dalam mendistribusian game ke sekolah dasar tidak dilakukan karena hanya di ujicobakan pada mahasiswa Program Studi Pendidikan Guru Sekolah Dasar Fakultas Keguruan dan Ilmu Pendidikan Universitas Mataram untuk melihat sejauh mana tanggapan pengguna terhadap media pembelajaran yang telah dikembangkan. Alasan utama mengapa pengujian media hanya dilakukan kepada mahasiswa adalah hampir semua mahasiswa di Prodi PGSD FKIP Universitas Mataram memiliki smartphone dengan operating system Android. Selain itu hampir semua sekolah dasar di Kota Mataram melarang peserta didiknya untuk membawa gadget atau smartphone ke lingkungan sekolah.

Aspek-aspek yang divalidasi oleh ahli media adalah operasional navigasi, kemudahan, tampilan, teks/tulisan, serta kualitas visual. Aspek operasional navigasi yang terdiri dari manfaat penyajian dari navigasi, ketepatan dari navigasi serta efisiensi dari navigasi. Rata-rata hasil validasi ahli pada aspek operasional navigasi adalah 3,83 dengan kriteria layak. Dalam game "Kata Fisika" tidak terdapat banyak tombol-tombol navigasi dan secara umum mudah dioperasikan bahkan untuk anak-anak pada tingkat sekolah dasar.

Aspek kemudahan yang mencakup kemudahan media untuk dioperasikan, kemenarikan materi dan animasi/gambar dari media, ketepatan penggunaan bahasa instruksi yang mudah dimengerti, serta kemudahan dalam memahami guna pemberian jawaban. Rata-rata hasil validasi ahli pada aspek kemudahan adalah 3,88 dengan kriteria layak. Pada game "Kata Fisika" bahasa maupun gambar yang disajikan tidak ada yang ambigu atau bermakna ganda serta peserta didik lebih mudah dalam memberikan jawaban karena setiap kata istilah yang ditemukan ditandai dengan warna arsiran yang berbeda. Tanda arsiran warna yang berbeda ini tentu saja memberikan kemudahan bagi pengguna dalam mencari istilah berbeda yang jumlahnya ada 10 (sepuluh) istilah yang ada pada materi konsep gaya.

Pada aspek kualitas visual yang mencakup kesesuaian gambar, warna, jenis huruf, dan letak (layout), ketepatan tata letak gambar, kesesuaian tema yang digunakan, ketepatan dalam penempatan konten materi, kesesuaian desain latar yang ditampilkan, kesesuaian warna, tulisan, dan animasi dengan background. Rata-rata hasil 
validasi ahli pada aspek kualitas visual adalah 3,58 dengan kriteria layak. Dari segi tata letak tampilan game masih tergolong sederhana dan masih belum kaya konten sehingga desain kualitas visual perlu ditingkatkan.

Hasil proses validasi oleh ahli media diketahui bahwa aspek yang memperoleh penilaian tertinggi adalah tampilan teks atau tulisan dengan ratarata 4,5 (sangat layak). Aspek lainnya yang dinilai oleh ahli media adalah operasional navigasi, kemudahan penggunaan, serta kualitas visual (tampilan). Aspek tampilan teks atau tulisan mendapatkan penilaian tertinggi oleh validator ahli media karena kejelasan tulisan dan keterbacaan tampilan teks yang disajikan sudah sangat jelas dan ketepatan penggunaan teks sesuai dengan istilah-istilah konsep yang terdapat pada buku guru sekolah dasar pada materi konsep gaya.

Aspek Pembelajaran yang divalidasi oleh ahli materi mencakup sub-sub aspek diantaranya Kesesuaian tujuan pembelajaran dengan Standar Kompetensi/Kompetensi Dasar, Kejelasan media yang disajikan dengan tujuan pembelajaran, Kesesuaian antara media, materi, dan evaluasi, Kejelasan tutorial dalam penyajian, Konsistensi Pemberian umpan balik, Ketepatan media dalam menciptakan motivasi belajar siswa, Ketepatan media sebagai pengembang kemandirian belajar siswa, serta Kemenarikan pola pembelajaran, bersifat menyenangkan namun menantang. Rata-rata hasil validasi ahli media pada aspek pembelajaran adalah 3,25 dengan kriteria layak. Ciri khas materi pembelajaran pada tingkat sekolah dasar adalah Pembelajaran tematik maka tidak semua materi pembelajaran yang ada pada setiap sub tema dapat diikutkan. Materi Konsep gaya yang disajikan juga masih terlalu sedikit.
Aspek substansi materi yang divalidasi oleh ahli materi mencakup sub-sub aspek diantaranya adalah kebenaran penyajian materi, kemenarikan penyajian materi, kesesuaian tingkat kesulitan materi, kedalaman dan cakupan materi, kontektualitas dan aktualitas materi, serta ketepatan bahasa yang digunakan. Rata-rata hasil validasi ahli media pada aspek substansi materi adalah 3,33 dengan kriteria layak. Dari segi substansi materi, game ini secara khusus hanya membahas tentang istilahistilah yang ada pada materi konsep gaya yang semuanya sudah disampaikan dengan bahasa yang tepat sesuai tingkatan peserta didik di tingkat sekolah dasar.

Penilaian ahli materi pada aspek bahasa yang meliputi ketepatan penggunaan bahasa yang mudah dipahami, kejelasan bahasa pada uraian dan pembahasan, serta media pembelajaran bersifat komunikatif kurang lebih sama dengan Aspek kemudahan pemakaian yang mencakup kejelasan petunjuk teknis belajar dan kemudahan memahami alur belajar (sistematis). Aspek bahasa dan aspek kemudahan pemakaian masing-masing memperoleh nilai rata-rata 4,17 dengan kriteria sangat layak, dan 3,00 untuk rata-rata kemudahan pemakaian dengan kriteria cukup. Bahasa dalam game ini memang sudah disesuaikan dengan peserta didik tingkat sekolah dasar yang mensyaratkan tidak terlalu banyak istilah yang sulit untuk disebutkan serta mudah dalam memberikan contoh atau aplikasinya dalam kehidupan sehari-hari yang berkaitan dengan konsep gaya.

Hasil validasi ahli materi
diketahui bahwa aspek bahasa
mendapatkan nilai tertinggi
dibandingkan aspek-aspek lain yang
dinilai oleh validator ahli materi. Hal
ini tidaklah mengherankan karena sub-


aspek yang ada pada aspek bahasa yaitu ketepatan penggunaan bahasa yang mudah dipahami, kejelasan bahasa pada media pembelajaran, serta sifat komunikatif semuanya hampir tepenuhi dan sesuai dalam mendukung proses pembelajaran mengenai konsep gaya pada tingkat sekolah dasar kelas IV (empat) Tema 7 Indahnya Keragaman di Negeriku. Feedback yang diperoleh dari ahli materi terhadap media pembelajaran adalah istilah-istilah yang berkaitan dengan IPA terutama pada materi Konsep Gaya perlu diperbanyak karena pada media pembelajaran game edukasi "Kata Fisika" yang dikembangkan hanya terbatas pada 10 (sepuluh) istilah yang ada pada materi Konsep Gaya.

Analisis uji coba pada pengguna diperoleh rata-rata skor sebesar 4,15 dengan kategori sagat layak. Sebagian besar item pertanyaan pada angket yang diujikan pada pengguna berkaitan dengan minat dan motivasi peserta didik dalam belajar dengan media pembelajaran game edukasi "Kata Fisika" berbasis sistem operasi Android.

Butir atau item pada angket yang diberikan kepada pengguna selain terdiri atas pertanyaan maupun pernyataan yang bersifat positif juga disertai dengan pertanyaan maupun pertanyaan yang sifatnya negatif. Penilaian pernyataan atau pertanyaan yang sifatnya terbalik (negatif) dilakukan dengan penilaian terbalik juga dimana jawaban pengguna yang tidak setuju dengan pertanyaan maupun pernyataan negatif tersebut memperoleh skor tertinggi.

Butir-butir pernyataan positif pada angket pengguna meliputi motivasi peserta didik untuk belajar IPA setelah menggunakan game edukasi "Kata Fisika", peserta didik merasa senang belajar IPA dengan media pembelajaran game edukasi "Kata
Fisika", peserta didik termotivasi untuk mendapatkan skor tertinggi dalam game edukasi "Kata Fisika", kemudahan mengoperasikan dan memahami media game edukasi "Kata Fisika", peserta didik memahami tujuan pembelajaran dari media game edukasi "Kata Fisika", peserta didik banyak belajar tentang materi Gaya dari game edukasi "Kata Fisika", peserta didik merasa tertarik dengan model permainan dan animasi game edukasi "Kata Fisika", serta peserta didik mempunyai gaya belajar baru dengan media game edukasi "Kata Fisika".

Butir pernyataan negatif pada angket pengguna diantaranya tentang peserta didik merasa tidak bersemangat dalam mengaplikasikan pembelajaran IPA dari media pembelajaran game edukasi "Kata Fisika", peserta didik tidak terlalu ambil pusing dengan menggunakan apa mereka belajar IPA, kendala peserta didik saat mengoperasikan game edukasi "Kata Fisika", kemenarikan tampilan game edukasi "Kata Fisika" yang disajikan, adanya game edukasi "Kata Fisika" membuat peserta didik kurang termotivasi untuk memahami konsep gaya, serta kurang terampilnya peserta didik dalam menggunakan smartphone sehingga media game edukasi "Kata Fisika" ini menjadi kurang begitu menarik.

Nilai rata-rata angket baik itu angket yang ditujukan pada ahli media pembelajaran, ahli materi tingkat sekolah dasar, serta pengguna (user) yang tinggi tentunya mengindikasikan bahwa adanya game edukasi "Kata Fisika" mempengaruhi minat dan motivasi pengguna dalam belajar khususnya tentang konsep gaya.

Penggunaan game edukasi sebagai media pembelajaran mempunyai kontribusi yang positif dalam proses pembelajaran (Turan et 
al., 2020). Selain itu hasil penelitian ini juga didukung oleh Hasil observasi Pelaksanaan PAKOM di MIM Potronayan 1 dan MIM PK Kenteng yang dilakukan oleh Supriyono dkk. yang menunjukkan bahwa program aplikasi yang diterapkan mampu meningkatkan motivasi belajar peserta didik walaupun sekolah memiliki keterbatasan spesifikasi perangkat komputer yang dimiliki oleh guru-guru di sekolah mitra (Supriyono, Murtiyasa, Rahmadzani, \& Adhantoro, 2018).

Penggunaan game edukasi sebagai media pembelajaran dapat menjadi mengasyikkan karena selain pengguna dilatih keterampilannya untuk fokus dalam mencari kata istilah dalan bidang fisika, pengguna juga dapat bertanding melalui skema permaian tambahan berupa adu cepat dalam menemukan kata istilah berdasarkan ketiga level permainan.

\section{KESIMPULAN}

Tingkat kelayakan media yang telah diuji validasi oleh ahli media adalah 3,88 (Layak) dan uji validasi oleh ahli materi adalah 3,35 (Layak), serta hasil uji ke pengguna diperoleh rata-rata 4,15 (Sangat Layak). Berdasarkan hasil yang diperoleh, game edukasi "Kata Fisika" berbasis Android ini dikategorikan layak dan dapat digunakan dalam pembelajaran materi Konsep Gaya pada peserta didik tingkat Sekolah Dasar.

\section{DAFTAR PUSTAKA}

Akbas, Y., \& Gencturk, E. (2011). The Effect of Conceptual Change Approach to Eliminate 9th Grade High School Students' Misconceptions about Air Pressure. Educationals Sciences: Theory \& Practice, 2217-2222.

Azizah, I. M. (2016). EFEKTIVITAS

PEMBELAJARAN
MENGGUNAKAN PERMAINAN
TRADISIONAL TERHADAP
MOTIVASI DAN HASIL
BELAJAR MATERI GAYA DI
KELAS IV MIN NGRONGGOT
NGANJUK. Dinamika Penelitian,
16(2), 279-308.

Baek, S., Park, J.-Y., \& Han, J. (2016). Simulation-based Serious Games for Science Education and teacher assessment. International Journal of Serious Games, 3(3). https://doi.org/10.17083/ijsg.v3i3.1 23

Besttoolbars. (2020). ABOUT APPSGEYSER APP CREATOR. Retrieved from http://appsgeyser.com/about/

Chiappetta, E. L., \& Koballa, T. R. J. (2014). Science Instruction in the Middle and Secondary Schools. New York: Allyn \& Bacon.

CHILDWISE. (2017). Press release: Childhood 2017 For children and teenagers, it is increasingly all about mobile.

Connolly, T. M., Boyle, E. A., MacArthur, E., Hainey, T., \& Boyle, J. M. (2012). A systematic literature review of empirical evidence on computer games and serious games. Computers \& Education, 59(2), 661-686. https://doi.org/10.1016/j.compedu. 2012.03.004

Erfan, M., \& Ratu, T. (2017). MENINGKATKAN MINAT DAN HASIL BELAJAR MAHASISWA PADA PERKULIAHAN ELEKTRONIKA DASAR MELALUI DIGITAL GAME- 
BASED LEARNING. Prosiding Seminar Nasional Pendidik Dan Pengembang Pendidikan Indonesia Dengan Tema "Membangun Generasi Berkarakter Melalui Pembelajaran Inovatif," 332-337.

Erfan, M., \& Ratu, T. (2018). Analysis of Student Difficulties in Understanding The Concept of Newton's Law of Motion. JIPF (Jurnal Ilmu Pendidikan Fisika), 3(1), $\quad 1-4$. https://doi.org/10.26737/jipf.v3i1.1 61

Falahudin, I. (2014). Pemanfaatan Media dalam Pembelajaran. Jurnal Lingkar Widyaiswara, 1(4), 104117. Retrieved from http://juliwi.com/published/E0104/ Paper0104_104-117.pdf

Fujiati, F., Nasari, F., Rahayu, S. L., \& Sanjaya, A. (2018). Educational Game as a Learning Media Using DGBL and Forward Chaining Methods. The 6th International Conference on Cyber and IT Service Management (CITSM 2018).

Karo-Karo, I. R., \& Rohani. (2018). MANFAAT MEDIA DALAM PEMBELAJARAN. AXIOM : JURNAL PENDIDIKAN DAN MATEMATIKA, 7(1), 91-96.

$\begin{array}{lrr}\text { Laksana, D. N. } & \text { L. } & \text { (2017). } \\ \text { MISKONSEPSI } & \text { DALAM } \\ \text { MATERI IPA } & \text { SEKOLAH } \\ \text { DASAR. JPI } & \text { (Jurnal } & \text { Pendidikan } \\ \text { Indonesia), } & 5(2), & 873 . \\ \text { https://doi.org/10.23887/jpi- } & \\ \text { undiksha.v5i2.8588 } & \end{array}$

Liu, T.-Y. (2016). Using educational games and simulation software in a computer science course: learning achievements and student flow experiences. Interactive Learning Environments, 24(4), 724-744. https://doi.org/10.1080/10494820.2 014.917109

Mahnun, N. (2012). MEDIA PEMBELAJARAN (Kajian terhadap Langkah-langkah Pemilihan Media dan Implementasinya dalam Pembelajaran). Jurnal Pemikiran Islam, 37(1), 27-34.

Millward Brown. (2014). AdReaction: Marketing in a multiscreen world. Retrieved from ttps://www.millwardbrown.com/ad reaction/2014/report/MillwardBrown_AdReaction2014_Global.pdf

$\begin{array}{cr}\text { Muhson, } & \text { A. } \\ \text { PENGEMBANGAN } & \text { MEDIA } \\ \text { PEMBELAJARAN } & \text { BERBASIS } \\ \text { TEKNOLOGI } & \text { INFORMASI. } \\ \text { Jurnal Pendidikan } & \text { Akuntansi } \\ \text { Indonesia, } & 8(2) . \\ \text { https://doi.org/10.21831/jpai.v8i2. } \\ 949\end{array}$

Nagle, A., Wolf, P., Riener, R., \& Novak, D. (2014). The Use of Player-centered Positive Reinforcement to Schedule Ingame Rewards Increases Enjoyment and Performance in a Serious Game. International Journal of Serious Games, 1(4). https://doi.org/10.17083/ijsg.v1i4.4 7

Panier, M. (2019). Infographic: the 25 Most Downloaded Games of the Entire History of Google Play 
Store. Retrieved January 31, 2020, from TheTool website: https://thetool.io/2019/25-bestgames-google-play-infographic

Rais, M., Aryani, F., Ahmar, A. S., Arfandi, H., \& Ahmad, W. K. (2018). Learning Media EduGames "My Profession" as an Effort to Introduce Various Types of Profession in Early Childhood Education Students. Journal of Physics: Conference Series, 1028, 012091.

https://doi.org/10.1088/17426596/1028/1/012091

Ramdhani, M. A., \& Muhammadiyah, H. (2015). The Criteria of Learning Media Selection for Character Education in Higher Education. International Conference of Islamic Educatios in Shoutheast Asia, (December 2015), 1-9.

Ramdhani, M. A., \& Wulan, E. R. (2012). The Analysis of Determinant Factors in Software Design for Computer Assisted Instruction. International Journal of Scientific \& Technology Research, 1(8), 69-73.

Supriyono, H., Murtiyasa, B., Rahmadzani, R. F., \& Adhantoro, M. S. (2018). PENERAPAN GAME EDUKATIF UNTUK MENINGKATKAN MOTIVASI BELAJAR SISWA SETINGKAT MADRASAH IBTIDAIYAH. WARTA LPM, 12(1), 30-39.

Suyadi. (2014). Teori pembelajaran Anak Usia Dini: dalam kajian Neurosains. Bandung: PT Remaja Rosdakarya.

Tafonao, T. (2018). PERANAN

$\begin{array}{lr}\text { MEDIA } & \text { PEMBELAJARAN } \\ \text { DALAM } & \text { MENINGKATKAN } \\ \text { MINAT } & \text { BELAJAR } \\ \text { MAHASISWA. } & \text { Jurnal }\end{array}$

Komunikasi Pendidikan, 2(2), 103. https://doi.org/10.32585/jkp.v2i2.1 13

Timur, S. (2012). Preschool Teachers Concerning the Subject "Force and Motion." Educationals Sciences: Theory \& Practice, 3038-3049.

Turan, G. Y., Köklükaya, A. N., \& Y1ldırım, E. G. (2020). Improving Matter and Heat Subjects Learning Through Genuine Designed Educational Games. International Journal of Science and Mathematics Education, 18(1), 1942. https://doi.org/10.1007/s10763018-09945-0

Tursinawati. (2013). ANALISIS KEMUNCULAN SIKAP ILMIAH SISWA DALAM PELAKSANAAN PERCOBAAN PADA PEMBELAJARAN IPA DI SDN KOTA BANDA ACEH. Jurnal Pionir, 1(1), 67-84. 